\title{
THE BIOECONOMY MODEL IN FUTURE SUSTAINABLE DEVELOPMENT
}

\author{
Ipate Nicolae \\ Romanian Academy - INCE-CSCBA \\ E-mail: ipate.iudith@gmail.com. \\ David Katalin Gabriela \\ Vasile Goldis West University of Arad \\ E-mail: dvd_gbr@yahoo.com \\ Ipate Iudith \\ Romanian Academy - INCE-CSCBA \\ Bogdan Alexandru \\ Romanian Academy - INCE-CSCBA
}

(Received April 2015; accepted June 2015)

\begin{abstract}
The future of sustainable development is the bioeconomy with the "global" solution; both global and local action for developed the renewable energy generation. When local solutions are implemented is being laid for global solutions are positive affect the national economy. The implementation of the bioeconomy strategy used by society to prevent urgent problems, such as increasing competition for natural resources, climate change, rural sustainable development. The bioeconomy is a new economic and social order and promotes systemic change from using non-renewable resources to renewables. Bioeconomy reveals that production, which involves the transformation of a limited stock of matter and energy, but respecting the same laws that govern entropy closed systems, the entropy or unavailable matter and energy in the forms tend to increase continuously. Economic growth not only increases the apparent output per unit of inputs, which is performed using finite stock of matter and energy in the world. The current economy is based on fossil fuels and other material inputs suffering entropic degradation, both in the raw material extraction and pollution. The production, even if technical progress leads to lower overall yields. The idea of a steady state as the final economic growth that perpetuated indefinitely pendulum model is an impossibility.
\end{abstract}

Key words: eco-innovation, biomass, food security, rural development

J.E.L. CODES: Q 270

\section{Introduction}

The romanian scientist Nicholas Georgescu-Roegen introduces the concept of sustainable decrease or decrease controllable in opposition to liberal economy and the concept of sustainable development. He believes that sustainable development endanger the natural balance of the planet because its resources are limited and nonrenewable. He also believes that Earth cannot sustain the current level of 
Ipate, N., David K.G., Ipate, I., Bogdan, A.T., (2015)

The bioeconomy model in future sustainable development

consumption indefinitely and needs especially people in rich countries to reduce their current level of physical and energy consumption.

The main goals of bio-economy is to reducing the dependency of global economy on fossil resources and mitigating climate change and need of renewable biological resources for food security and energy security. Specific objectives of bioeconomy are to find the more sustainable industry and energy production, the efficient resources in agriculture for sustainable production of renewable materials and alternative energy and carbon sources. The bio-economy it is important because promotes the production of renewable biological resources, and their conversion into food, bio-based products and bio-energy. The bio-based products is describes as bio refers to renewable biological resources and not to biotechnology. The main message of the fourth law of thermodynamics - discovered of Nicolas Georgescu Roegen is: "You cannot use the same amount of matter and energy than once" or otherwise "Cannot use the same amount of entropy than once ". This law proclaims to matter what the proclaim energy second law of thermodynamics. There is one important difference, namely that in an isolated system (which does not change the matter with the environment) instead of the trend towards heat death (when all energy is unavailable, is unusable, reach absolute zero temperature) there is a tendency towards chaos (when all matter and energy is unusable). Roegen argued no that - no chemical energy decreases or increases. But its potential energy is dispersed in starting such an extent as smoke and ash, that men can no longer use". This amount of energy was unavailable or unusable degraded energy. Available energy or potential "free" explains Nicholas Georgescu-Roegen, "is the energy that is of a quality and differentiated level" as differentiated temperature inside a boiler to boiler temperature outside. "Energy is an energy dispersed unavailable disorder", which is not lost but is dissipated in the atmosphere and unavailable for further use. Low entropy refers to a structure in which the energy is available and the high entropy refers to a structure in which power is unavailable. All of Earth's energy reserves, known and likely could provide two weeks of sunlight on Earth. "It might sound surprising - Nicholas Georgescu-Roegen shows - all natural resources fund is worth more than a few days of sunshine! Any innovation process (actually any economic process), "a continuous transformation process and irrevocable low entropy into high entropy".

Management of the bio-economy would imply: optimizing resource allocation as "food versus fuel" debate; driving research and innovation in the primary production and processing sectors; developing new industrial concepts and business models, and open new markets and the creation of new high-skill jobs. In February 2012 in the framework of the EU 2020 Strategy for smart and green growth, the European Commission present the Communication "Innovating for Sustainable Growth: a Bio-economy for Europe". This Communication it is a Bio- 
Ipate, N., David K.G., Ipate, I., Bogdan, A.T., (2015)

The bioeconomy model in future sustainable development

economy Strategy and the Action Plan for promoting a more sustainable use of renewable biological resources within the European economy. The aim of the strategy is to ensure continued supply of safe and healthy food and feed, as well as for materials, energy, and other products (DGRTD, 2012). EU bio-economy is based to research, development and innovation5, for uses the local biological renewable resources from land and sea.

\section{Material and methods}

For analyzed the actual situation in Romania in the context of implementation the european bioeconomy strategy we analyzed the indicators: socio-economic context with: GDP per capita (fig.1), population (fig.2), population density, human development index; Natural asset base in context the: average deforestation, $\%$ of land area, Terrestrial and marine protected areas; environmental and resources productivity in the context of: $\mathrm{CO} 2$ emissions per capita (fig.3) and carbon productivity; Environmental quality of life with: population exposure to air pollution, access to improved sanitation, access to improved water source, access to electricity; renewable electricity using the GGKP data explorer.

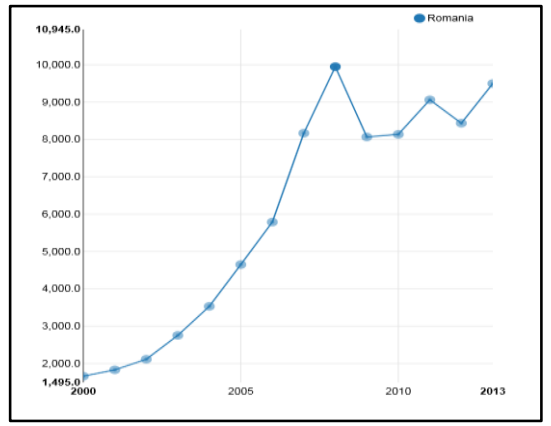

Figure 1. GDP for capita

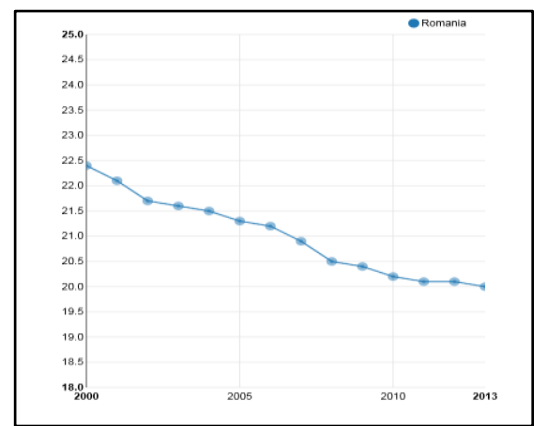

Figure 2. Population

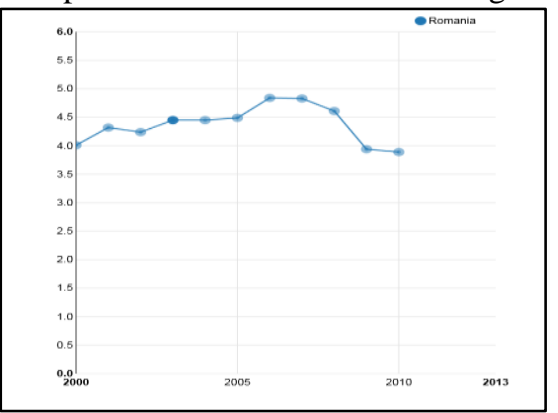

Figure 3. $\mathrm{CO} 2$ emision / capita 
Ipate, N., David K.G., Ipate, I., Bogdan, A.T., (2015)

The bioeconomy model in future sustainable development

The following example will be estimated and a regression equation to illustrate a model carbon productivity with use the series data of the water exploitation index (WEI), population in Romania and greenhouse gas emissions by sector (1000 tones of CO2 equivalent)- GGE, using in period: 1990-2014. Series used: water exploitation index (WEI) - population (POP), greenhouse gas emissions (GGE) by sector (1000 tones of CO2 equivalent) since 1990 with the data source: www.insse.ro-Tempo-online database and GDP per capita, carbon productivity (CARBONPROD), $\mathrm{CO} 2$ emissions per capita (CO2emision) with the data sources GGKP data explorer. For a description of the analyzed phenomenon we built a model of the form:

$\mathrm{D}(\mathrm{CARBONPROD})=\mathrm{C}(1) *(\mathrm{GGE})+\mathrm{C}(2) * \mathrm{POP}+\mathrm{C}(3) * \mathrm{CO} 2 \mathrm{EMISION}+\mathrm{C}(4) * \mathrm{GDP}+\mathrm{C}(5) * \mathrm{WEI}$ $+\mathrm{C}(6) * \mathrm{~T}+\mathrm{C}(7) * \mathrm{~T}^{2}+\mathrm{C}(8)$

Dependent Variable: D(CARBONPROD)

Method: Least Squares

Date: 04/28/15 Time: 19:59

Sample (adjusted): 19912014

Included observations: 24 after adjustments

$\mathrm{D}(\mathrm{CARBONPROD})=\mathrm{C}(1) * \mathrm{GGE}+\mathrm{C}(2) * \mathrm{POP}+\mathrm{C}(3) * \mathrm{CO} 2 \mathrm{EMISION}+\mathrm{C}(4)$

$* \mathrm{GDP}+\mathrm{C}(5) * \mathrm{WEI}+\mathrm{C}(6) * \mathrm{~T}+\mathrm{C}(7) * \mathrm{~T}^{\wedge} 2+\mathrm{C}(8)$

\begin{tabular}{crccc}
\hline \hline & Coefficient & Std. Error & t-Statistic & Prob. \\
\hline \hline C(1) & $6.65 \mathrm{E}-07$ & $4.24 \mathrm{E}-06$ & 0.156677 & 0.8775 \\
$\mathrm{C}(2)$ & $-3.90 \mathrm{E}-06$ & $6.03 \mathrm{E}-06$ & -0.646137 & 0.5274 \\
$\mathrm{C}(3)$ & -0.003684 & 0.002594 & -1.419985 & 0.1748 \\
$\mathrm{C}(4)$ & 0.002401 & 0.000989 & 2.428762 & 0.0273 \\
$\mathrm{C}(5)$ & 0.003833 & 0.005197 & 0.737656 & 0.4714 \\
$\mathrm{C}(6)$ & 1.040974 & 1.096981 & 0.948944 & 0.3568 \\
$\mathrm{C}(7)$ & -0.100168 & 0.034817 & -2.877032 & 0.0110 \\
$\mathrm{C}(8)$ & 95.77205 & 138.3140 & 0.692425 & 0.4986 \\
\hline \hline R-squared & 0.546779 & Mean dependent var & 3.875000 \\
Adjusted R-squared & 0.348495 & S.D. dependent var & 4.739405 \\
S.E. of regression & 3.825453 & Akaike info criterion & 5.782432 \\
Sum squared resid & 234.1454 & Schwarz criterion & 5.175117 \\
Log likelihood & -61.38919 & Hannan-Quinn criter. & 2.070017 \\
F-statistic & 2.757550 & Durbin-Watson stat & \\
Prob(F-statistic) & 0.044033 & & \\
\hline \hline
\end{tabular}

Estimation Command:

$\mathrm{LS}$ D(CARBONPROD) $=\mathrm{C}(1) * \mathrm{GGE}+\mathrm{C}(2) * \mathrm{POP}+\mathrm{C}(3) * \mathrm{CO} 2 \mathrm{EMISION}+\mathrm{C}(4) * \mathrm{GDP}+\mathrm{C}(5) * \mathrm{WEI}$ $+\mathrm{C}(6) * \mathrm{~T}+\mathrm{C}(7) * \mathrm{~T}^{\wedge} 2+\mathrm{C}(8)$ 
Ipate, N., David K.G., Ipate, I., Bogdan, A.T., (2015)

The bioeconomy model in future sustainable development

Estimation Equation:

$\mathrm{D}(\mathrm{CARBONPROD})=\mathrm{C}(1) * \mathrm{GGE}+\mathrm{C}(2) * \mathrm{POP}+\mathrm{C}(3) * \mathrm{CO} 2 \mathrm{EMISION}+\mathrm{C}(4) * \mathrm{GDP}+\mathrm{C}(5) * \mathrm{WEI}$ $+\mathrm{C}(6) * \mathrm{~T}+\mathrm{C}(7) * \mathrm{~T}^{\wedge} 2+\mathrm{C}(8)$

Substituted Coefficients:

$\mathrm{D}(\mathrm{CARBONPROD})=6.646 \mathrm{GGE}-3.897 * \mathrm{POP}-0.0036 * \mathrm{CO} 2 \mathrm{EMISION}+0.0024 * \mathrm{GDP}+0.0038 * \mathrm{WEI}$ $+1.0409 * \mathrm{~T}-0.100168 * \mathrm{~T}^{\wedge} 2+95.77$

\section{Results and discussion}

In the model developed there is a direct relationship between carbon productivity (CARBONPROD), GDP per capita, CO2 emissions per capita (CO2emision), water exploitation index (WEI), population growth POP, and the greenhouse gas emissions (GGE).

The coefficient of greenhouse gas emissions (GGE) is $\hat{\beta}_{2}=6.4, \operatorname{SE}\left(\hat{\beta}_{2}\right)=4,42$, and statistic $\hat{\mathrm{t}}_{2}=0,15$. The value of this probability is 0.87 . The value of $t$ calc is higher than the value of $t$ table and therefore greenhouse gas emissions (GGE) is an important factor influencing the carbon productivity index.

The coefficient of population growth (POP) from regression model it is $\hat{\beta}_{1}=3,90$ and standard error $\operatorname{SE}\left(\hat{\beta}_{1}\right)=6,03$, and statistic $\hat{t}_{1}=0.64$, calculated: $\hat{\mathrm{t}}_{1}=\frac{\hat{\beta}_{1}}{\mathrm{SE}(\hat{\beta})_{1}}=\frac{\text { Coefficien } \mathrm{t}}{\text { Std.Error }}$; valoarea $\mathrm{p}(p$ value $)=0.52$, which shows that the population is an important factor influencing the water exploitation index carbon productivity. The coefficient constant term in the regression model is $=95,77$, standard error $=138, \mathrm{t}$-statistic $=0.69$ expressed, with probability $\mathrm{p}$ value of 0.49 . So the term is significant endorsement for the regression model chosen.

Report of determination (R2- 0,54) shows the percentage is explained by the influence of significant factors. It is calculated as: use in assessing the quality of the model. It can take only values in the range $[0,1]$. The values are closer to the value 1 , the model is better. The regression model is specified in this period we can say that growth can explain variation greenhouse gas emissions (GGD) with water exploitation index (WEI) consumption.

Were tested by the equation errors View / Residual tests / Correlogram - Q Correlogram of Residuals

Correlogram of D (carbon prod) 
Ipate, N., David K.G., Ipate, I., Bogdan, A.T., (2015)

The bioeconomy model in future sustainable development

Date: 04/28/15 Time: 20:31

Sample: 19902014

Included observations: 24

\begin{tabular}{|c|c|c|c|c|c|c|}
\hline Autocorrelation & Partial Correlation & & $\mathrm{AC}$ & PAC & Q-Stat & Prob \\
\hline & & 1 & 0.268 & 0.268 & 1.9494 & 0.163 \\
\hline & & 2 & -0.096 & -0.181 & 2.2128 & 0.331 \\
\hline & & 3 & -0.062 & 0.019 & 2.3280 & 0.507 \\
\hline * $*$ & $*$ & 4 & -0.093 & -0.107 & 2.5980 & 0.627 \\
\hline &.$\left.\right|^{*}$ & 5 & 0.079 & 0.147 & 2.8041 & 0.730 \\
\hline & $*$ & 6 & -0.042 & -0.159 & 2.8661 & 0.825 \\
\hline$* *$ & $*$ & 7 & -0.214 & -0.142 & 4.5448 & 0.715 \\
\hline$* \mid$ & & 8 & -0.110 & -0.037 & 5.0196 & 0.755 \\
\hline & . $\left.\right|^{*}$ & 9 & 0.055 & 0.084 & 5.1472 & 0.821 \\
\hline.$\left.\right|^{*}$ & & 10 & 0.140 & 0.057 & 6.0151 & 0.814 \\
\hline & $*$ & 11 & -0.023 & -0.117 & 6.0412 & 0.871 \\
\hline$*$ & $* 1$ & 12 & -0.146 & -0.071 & 7.1426 & 0.848 \\
\hline
\end{tabular}

According to this test, for all lags of errors no serial correlation of errors (autocorrelation coefficient does not exceed the rated range in the chart). The existence of autocorrelation test is invalidated and the Q-statistic and the associated probability.

Hetroscedasticity test was applied and revealed that there is a direct relationship between carbon productivity (CARBONPROD), GDP per capita, CO2 emissions per capita (co2emision), water exploitation index (WEI), population growth POP, and the greenhouse gas emissions (GGE).

Coefficient of the regression model is $=38.44$, standard error $=418.96$ and statistic $=0,091$, shows that is an important factor influencing the carbon productivity. Population coefficient is 3,26 , standard error 1.74 , and statistical $=0,18$. shows that is an important factor influencing the carbon productivity. GGE coefficient is 1,21 , standard error 1.36 , and statistical $=-0,89$. shows that is an no important factor in influencing the carbon productivity. CO2emision coefficient is $-0,015$ standard error 0,0084 , and statistical $=-1,77$. shows that is an no important factor in influencing the carbon productivity. The value of t calc (2.92) is less than the value of t table (2.71) so the population is not an important factor of influence of carbon productivity. Theoretically with GDP growth should increase the carbon productivity, but up to a certain level. 
Ipate, N., David K.G., Ipate, I., Bogdan, A.T., (2015)

The bioeconomy model in future sustainable development

Heteroskedasticity Test: Breusch-Pagan-Godfrey

\begin{tabular}{llll}
\hline \hline F-statistic & 1.259047 & Prob. F(6,17) & 0.3267 \\
Obs*R-squared & 7.383755 & Prob. Chi-Square(6) & 0.2868 \\
Scaled explained SS & 2.783714 & Prob. Chi-Square(6) & 0.8355 \\
\hline
\end{tabular}

Test Equation:

Dependent Variable: RESID^2

Method: Least Squares

Date: 04/28/15 Time: 20:25

Sample: 19912014

Included observations: 24

\begin{tabular}{crrrr}
\hline \hline Variable & Coefficient & Std. Error & t-Statistic & Prob. \\
\hline \hline C & 38.44302 & 418.9618 & 0.091758 & 0.9280 \\
GGE & $-1.21 \mathrm{E}-05$ & $1.36 \mathrm{E}-05$ & -0.891216 & 0.3853 \\
POP & $3.26 \mathrm{E}-06$ & $1.74 \mathrm{E}-05$ & 0.187211 & 0.8537 \\
CO2EMISION & -0.015043 & 0.008490 & -1.771744 & 0.0944 \\
GDP & 0.005337 & 0.003236 & 1.648995 & 0.1175 \\
WEI & -0.006950 & 0.012956 & -0.536464 & 0.5986 \\
$\mathrm{~T}$ & -2.925985 & 2.712811 & -1.078580 & 0.2958 \\
\hline \hline R-squared & 0.307656 & Mean dependent var & 9.756058 \\
Adjusted R-squared & 0.063300 & S.D. dependent var & 12.98064 \\
S.E. of regression & 12.56309 & Akaike info criterion & 8.137896 \\
Sum squared resid & 2683.129 & Schwarz criterion & 8.481495 \\
Log likelihood & -90.65475 & Hannan-Quinn criter. & 8.229053 \\
F-statistic & 1.259047 & Durbin-Watson stat & 2.659944 \\
Prob (F-statistic) & 0.326673 & & \\
\hline \hline
\end{tabular}

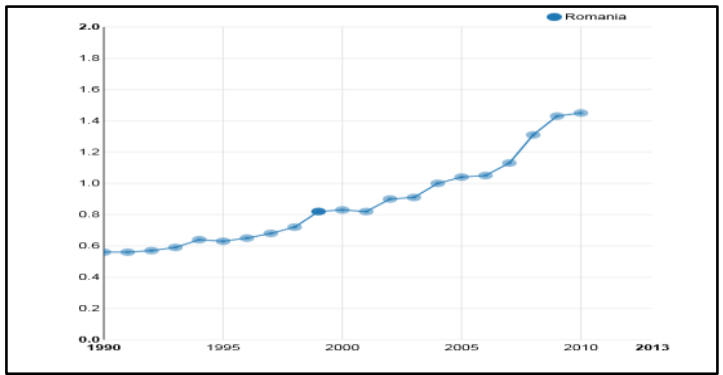

Fig.4 Carbon productivity in Romania

Sources: http://www.greengrowthknowledge.org/data 


\section{Conclusion}

The bioeconomy is a new economic and social order and promotes systemic change from using non-renewable resources to renewables. Bioeconomy reveals that production, which involves the transformation of a limited stock of matter and energy, but respecting the same laws that govern entropy closed systems, the entropy or unavailable matter and energy in the forms tend to increase continuously. Economic growth not only increases the apparent output per unit of inputs, which is performed using finite stock of matter and energy in the world. The current economy is based on fossil fuels and other material inputs suffering entropic degradation, both in the raw material extraction and pollution.

In our research we developed one model using the series from carbon productivity (carbon prod), GDP per capita, CO2 emissions per capita (co2emision), water exploitation index (WEI), population growth POP, and the greenhouse gas emissions (GGE). Theoretically with carbon productivity GDP growth should increase the water exploitation index (WEI), but up to a certain level. The econometric model has shown that carbon productivity index growth with GDP and $\mathrm{Co} 2$ emission per capita index needs at the individual level is approximately constant, being influenced by specific biological factors and influences population growth and greenhouse gas emissions, which directly influences can have negative impacts on biodiversity indicators.

\section{ACKNOWLEDGMENT}

This paper has been financially supported within the project entitled „SOCERT. Knowledge society, dynamism through research", contract number POSDRU/159/1.5/S/132406. This project is co-financed by European Social Fund through Sectoral Operational Programme for Human Resources Development 2007-2013. Investing in people!" and Research Program INCE- Theme: 6.2.7.

\section{References}

1. AT Bogdan, Ipate Iudith, Ecoeconomy and ecosanogenesis in Romania based of agrifood green power, Romanian Academy Editor 2012, ISBN 978-973-272264-0, 2012.

2. Braat, LC \& WFJ van Lierop, Integrated economic-ecological modeling, Elsevier Science Pub. Co., Amsterdam; New York 1987.

3. Brookshire, DS, LA Brand, J Thacher, MD Dixon, K Benedict, JC Stromberg, K Lansey, D Goodrich, M McIntosh, J Grandy, S Stewart, C Broadbent \& G Izon, Integrated modeling and ecological valuation: Applications in the semiarid southwest, paper presented at Workshop "Valuation for Environmental Policy: Ecological Benefits", Washington DC, April 23-24, 2007, 2007. 
4. Cai, X, DC McKinney \& L Lasdon, An integrated hydrologic-agronomiceconomic model for river basin management, $J$ Water Resour Plan Manage, 129(1), 4-17, 2003.

5. Eggert, H, Bioeconomic analysis and management, Environ Resour Econ, 11(3), 399-411, 1998.

6. Ewert, F, MK van Ittersum, I Bezlepkina, O Therond, E Andersen, H Belhouchette, C Bockstaller, F Brouwer, T Heckelei, S Janssen, R Knapen, M Kuiper, K Louhichi, JA Olsson, N Turpin, J Wery, JE Wien \& J Wolf, A methodology for enhanced flexibility of integrated assessment in agriculture, Environ Sci Policy, 12(5), 546-561, 2009.

7. Firth, $\mathrm{C}$, The use of gross and net margins in the economic analysis of organic farms, paper presented at UK Organic Research 2002: Proceedings of the COR Conference, Aberystwyth, 26-28th March 2002, 26-28th March 2002, 2001.

8. Gonzalez-Alvarez, Y, AG Keeler \& JD Mullen, Farm-level irrigation and the marginal cost of water use: Evidence from Georgia, J Environ Manag, 80(4), 311-317, 2006.

9. Grigalunas, T, JJ Opaluch \& M Luo, The economic costs to fisheries from marine sediment disposal: Case study of providence, USA, Ecol Econ, 38(1), 47-58, 2001.

10. Hanley, N \& EB Barbier, Pricing nature. Cost-benefit analysis and environmental policy, Edward Elgar, Cheltenham, UK, 2009.

11. Hazell, PBR \& RD Norton, Mathematical programming for economic analysis in agriculture, Macmillan, 1986.

12. Jula D., Jula N., 2010, Modelare economica. Modelele econometrice si de optimizare. Mustang, Bucuresti

13. OECD, The Political Economy of Environmentally Related Taxes, 2006, Paris, pp. $10-25$ 